\title{
Confidentiality, informed consent and children's participation in the Saudi biobank governance: a comparative study
}

G.H. Alahmad' and K. Dierickx ${ }^{2}$

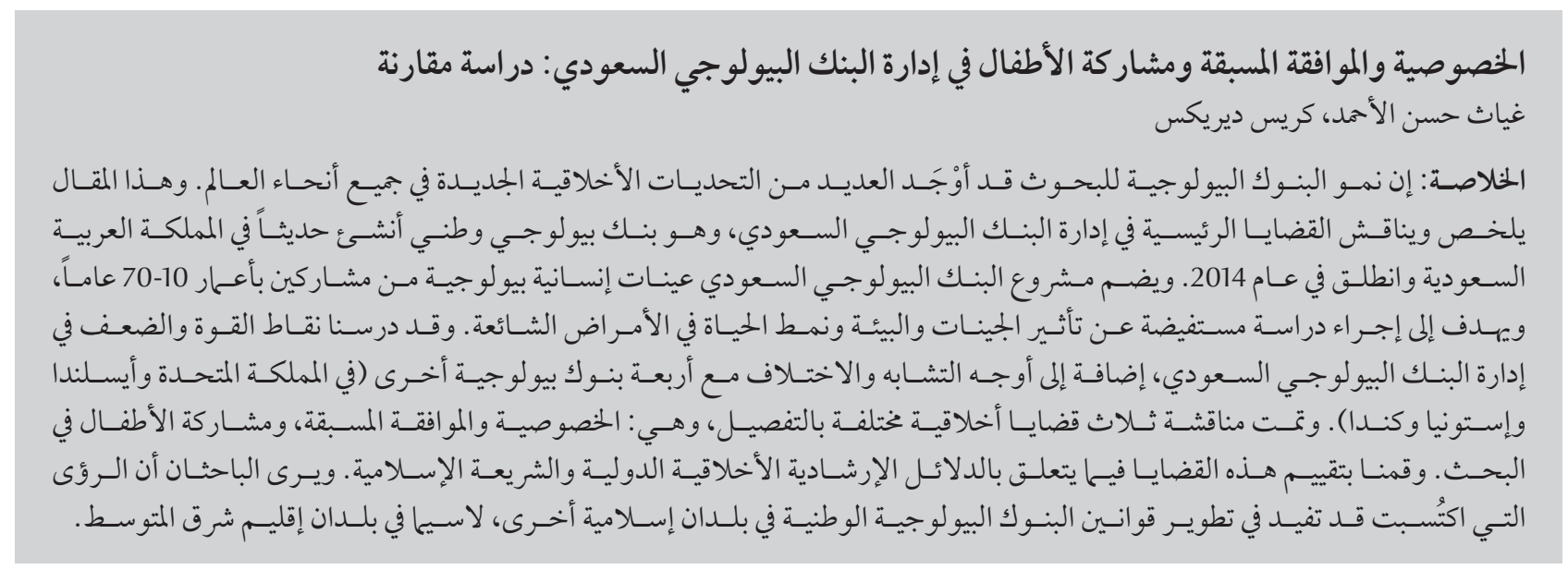

ABSTRACT The growth of research biobanks has created many new ethical challenges worldwide. This article outlines and discusses key issues in the governance of Saudi Biobank, a newly established national biobank in Saudi Arabia launched in 2014. The Saudi Biobank project includes human biological samples from participants aged 10-70 years and aims to conduct an extensive study on the influence of genes, environment and lifestyle in common diseases. We examined the strengths and weaknesses of Saudi Biobank's governance as well as the similarities and differences with 4 other biobanks (in the United Kingdom, Iceland, Estonia and Canada). Three different ethical issues are discussed in detail: confidentiality, informed consent and children's participation in research. We evaluated these issues in relation to international ethical guidelines and Islamic law. The insights gained may be useful in developing national biobanking regulations in other Islamic countries, particularly in countries of the Eastern Mediterranean Region.

Confidentialité, consentement éclairé et participation des enfants dans la gouvernance de la Biobanque saoudienne : étude comparative

RÉSUMÉ Le développement des biobanques de recherche a créé de nombreux nouveaux défis éthiques dans le monde. Le présent article décrit et aborde des questions clés concernant la gouvernance de la Biobanque saoudienne, une biobanque nationale créée récemment en Arabie saoudite, en 2014. Le projet de la Biobanque saoudienne porte sur des échantillons biologiques humains recueillis auprès de participants âgés de 10 à 70 ans et vise à mener une étude approfondie concernant l'influence des gènes, de l'environnement et du mode de vie sur les maladies les plus courantes. Nous avons examiné les forces et les faiblesses de la gouvernance de la Biobanque saoudienne ainsi que les similitudes et les différences avec quatre autres biobanques (au RoyaumeUni, en Islande, en Estonie et au Canada). Trois questions éthiques différentes sont abordées en détail : la confidentialité, le consentement éclairé et la participation des enfants à la recherche. Nous avons évalué ces questions par rapport aux directives internationales d'éthique et au droit islamique. Les connaissances recueillies peuvent être utiles pour l'élaboration d'une réglementation nationale des biobanques dans d'autres pays islamiques, notamment dans des pays de la Région de la Méditerranée orientale.

${ }^{7}$ King Abdullah International Medical Research Centre, Riyadh, Saudi Arabia. ${ }^{2}$ Centre for Biomedical Ethics and Law, Faculty of Medicine, Katholieke Universiteit Leuven, Leuven, Belgium (Correspondence to G.H. Alahmad: ghiathalahmad@hotmail.com).

Received: 08/01/13; accepted: 12/05/14 


\section{Introduction}

Research biobanks today play a significant role in advancing medical science by offering the necessary resources for conducting research involving large numbers of biological samples. However, these research biobanks have created many new ethical challenges. These include issues such as whether human sample donors should give broad consent for use of samples rather than specific consent for each research study; the risks to participants from breaches in confidentiality of data; the risk of misuse of genetic information; how children's participation should be handled; and whether there is any direct benefit to biobank participants (1). Scholars have studied these challenges to identify appropriate solutions, and as a result a number of different guidelines, regulations and laws concerning biobanks have arisen: for example, the UK Biobanks Governance (national guidelines) (2), the Guidelines for $\mathrm{Hu}$ man Biobanks and Genetic Research Databases from the Organization for Economic Co-operation and Development (OECD) (regional guidelines) (3), and the International Declaration on Human Genetic Data by the United Nations Educational, Scientific and Cultural Organization (UNESCO) (international guidelines) (4).

Saudi Biobank is a newly established national biobank in Saudi Arabia. Other new national biobanks in Middle Eastern countries have been launched ( $\mathrm{Q} a-$ tar Biobank) or are expected to launch in the near future, particularly in the Gulf region (5). The ethical standards and governance of any biobank are affected not only by general principles but also by the laws and ethos of the country. Saudi Biobank was designed in a manner to respect not only international guidelines and Saudi law but also Islamic values, as outlined by the Saudi Biobank governance document (6). It is stated that consideration will be given to Islamic sources to ensure that the biobank is compliant with Islamic law, especially the Holy Quran, sunna and other sources including the decisions of juristic councils, such as the Council of Senior Scholars in Saudi Arabia and International Islamic Fiqh Academy (IIFA). The International Ethical Guidelines for Biomedical Research involving Human Subjects_-Islamic View, published by the Islamic Organization for Medical Sciences (IOMS), in 2004 (7) is one of the references for the Saudi Biobank governance. Furthermore, the governance of Saudi Biobank considers as well the Saudi Arabian Law of Ethics of Research on Living Creatures of the National Committee of Medical and Bioethics. However, there is no clearly stated mechanism about how to apply Islamic opinions derived from these sources to the Saudi Biobank governance.

No previous studies have discussed the governance of Saudi Biobank. Moreover, there are a lack of published guidelines on genetic or general research ethics in the Eastern Mediterranean Region (EMR) (8). This paper aimed to perform a comparative analysis of the Saudi Biobank governance with that of different types of national or regional biobanks in other countries, particularly regarding the key topics of confidentiality, informed consent and children's participation, and how these are translated into the Islamic context. This paper will help future biobanks in the EMR, and areas with similar cultural and societal values and circumstances, to build their governance and to benefit from Saudi Biobank's strengths and weaknesses.

\section{Methods}

\section{Background: Saudi Biobank}

Saudi Biobank was established and co-financed by 2 governmental organizations: the King Abdul Aziz City for Science and Technology and the King Abdullah International Medical
Research which is a part of the National Guard Health Affairs (NGHA). The Saudi Biobank project aims to conduct an extensive study on the influence of genes, environment and lifestyle in common diseases (9).

Saudi Biobank plans to obtain human biological samples and collect data from approximately 200000 NGHA workers and their families. The NGHA has 4 large hospitals and 60 health centres (primary or secondary) with a total capacity of 2000 beds; it serves a community population of 2.5 million and approximately 60000 patients a year (9). Muslims are $97.1 \%$ of the Saudi population (10). The NGHA offers the following advantages: a high-quality health-care system, new programme development, information technology resources and strategic development. These factors were important in selecting the NGHA as the Saudi Biobank headquarters (9).

Saudi Arabia has a different demographic distribution of ages compared with Western nations, notably a high proportion of young people in the population. The population under 40 years old in Saudi Arabia is approximately $78 \%$ and under 15 years is $32 \%(11)$. Therefore, the biobank was set up to include samples from children aged from 10 years and adults up to 70 years (6).

\section{Data collection}

This article concentrates on Saudi Biobank's governance and how it addresses 3 basic ethical issues: informed consent, confidentiality and children's participation. The components of each of these ethical issues were analysed and compared with governance documents from other biobanks.

The study was carried out from June to December 2013. To make a proper evaluation of Saudi Biobank's governance, it was compared with the governance documents of 4 different biobanks selected from biobanks that fulfilled the following criteria: national or regional biobanks established for 
research purposes; ethical guidelines were accessible online to third parties from different countries; biobanks varied in size; and participants ranged in age. The selected biobanks were UK Biobank in the United Kingdom (2), Estonian Genome Project in Estonia (12), deCODE Genetics in Iceland (13) and CARTaGENE in Quebec, Canada (14).

Some of the international guidelines that address research biobank ethical issues are more general than explicit (15). Therefore, while we noted these guidelines we did not include them in our comparative results section but only referred to them in the discussion. These international guidelines included the Human Genome Organization's Ethics Committee (HUGO) statement (16), the Declaration of UNESCO (4), the World Health Organization's (WHO) report on genetic databases (17) and the guidelines of the OECD (3).

\section{Results}

The reviewed biobanks represent a varied picture of biobanks. They differ in many aspects, including the year of establishment, the number of participants and the participants' ages. Each biobank has its own system of ethics, which is guided by the general law of the country in which it is based.

\section{Confidentiality}

Confidentiality is a major concern in the governance of all the reviewed biobanks $(2,6,12-14)$. Different protection mechanisms are employed to guarantee the confidentiality of personal information (Table 1). The stored samples and data are coded and/or anonymized and kept under strict control and are protected by a good security system (2,6,12-14).

Preventing discrimination, i.e. actions against or negative attitudes towards a person based on variations in his or her genome (18), is mentioned in the governance documents of the Icelandic, Estonian and Saudi biobanks but not to the same degree $(6,12,13)$. In their statement on informed consent, the Estonian biobank states, "No one may discriminate against me on the basis of being or not being a gene donor" (12). The Icelandic biobank affirms avoiding discrimination: "It is prohibited to discriminate against a donor of a biological sample on the grounds of data derived from a biological sample" (13). In a special paragraph, Saudi Biobank's governance statement discusses preventing discrimination and outlines the levels: "Protection against any discrimination will be applied in the 3 levels: individuals, families and tribes" (6). Saudi Biobank also mentions preventing any type of stigmatization: i.e. socially or economically categorizing people according to their attitudes, stereotypes, beliefs (19) or medical conditions (20).

\section{Informed consent}

All biobanks are obligated by their governances to obtain informed consent from all participants prior to participation (Table 1) (2,6,12-14). The Icelandic biobank distinguishes between 2 groups of participants: healthy volunteers who donate for research purposes; and patients whose samples are collected initially for clinical reasons connected with their diagnosis and treatment but will be used later for research. Written signed informed consent is needed in the former case, while consent is assumed without the need of a donor's signature in the latter case, provided that the samples are not personally identified (13). Saudi Biobank requires written informed consent in both cases (6). Informed consent must contain all the information that is required to enable the participant to make a voluntary decision. General consent covering all types of research in the biobank is used by all biobanks, except the Icelandic biobank, deCODE Genetics, which provides 2 choices: either a limited consent for a specific research proposal; or a one-time broad consent that covers future research $(2,6,12-14)$.

Saudi Biobank, UK Biobank and the Canadian biobank, CARTaGENE, allow re-contacting of participants for the following reasons: to collect new information; to collect new consent for new uses; or to provide feedback on the results of the research $(2,6,14)$.

Withdrawal of consent at any time, without penalty, is a guaranteed right for all participants in all biobanks (Table 1). All the biobanks define different withdrawal options. Both Saudi Biobank and UK Biobank, for example, define 3 withdrawal options. The 1st option is the same in both biobanks: to have no further contact with the biobank. However, in the 2nd option UK Biobank will stop accessing samples and data, but Saudi Biobank will continue accessing them without collecting new samples or contacting donors. In the 3rd option Saudi Biobank mandates making anonymization irreversible, and will continue using previously collected samples after making them irreversibly anonymized. However, Saudi Biobank does not include an option for destruction of samples. This contrasts with UK Biobank (and the Icelandic biobank), which has an option to destroy samples after withdrawal from expressed consent. In the Estonian biobank the participants have the right to withdraw completely before coding (i.e. all samples and data to be removed), while after coding the participants have the right to apply for destruction only of the data which enables decoding. But in cases of unlawful disclosure of data, the gene donors to the Estonian biobank have the right to apply for the destruction of the tissue samples, the description of the DNA and the description of their state of health. For deCODE Genetics in Iceland, the biological sample will be destroyed when the donor withdraws written signed consent. On withdrawal of assumed consent, the biological sample shall not be destroyed, but preserved for use in the interests of the donor. 


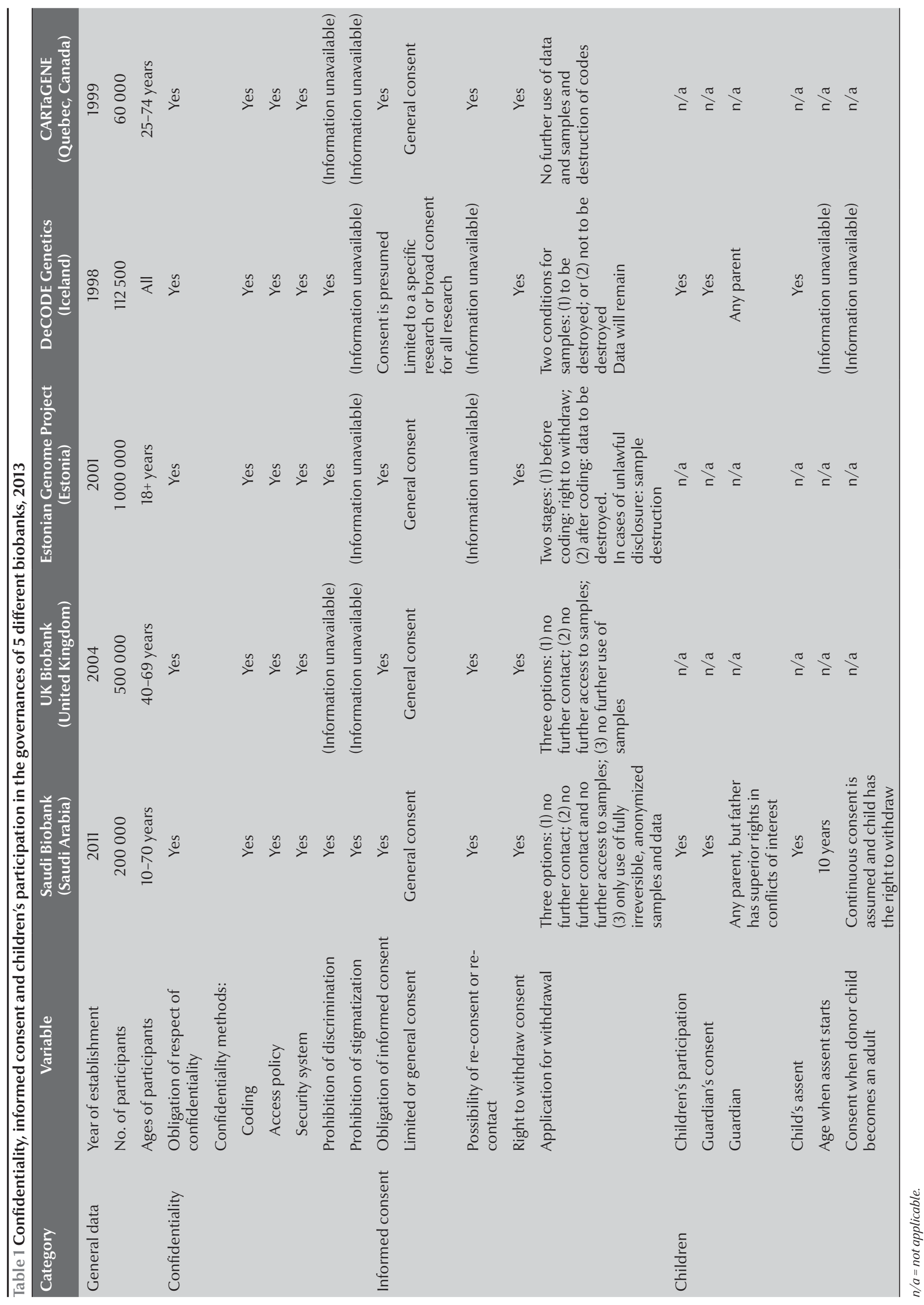


Also, on withdrawal, any data existing in the database will remain, but no new data will be entered. At CARTaGENE in Canada, after withdrawal of consent there is no further use of data or samples and there is destruction of codes, except for previous statistical analyses and publications (2,6,12-14).

\section{Children's participation}

Saudi Biobank and the Icelandic biobank, are familial biobanks that recruit samples from children (Table 1). While there is no minimum age of participants in deCODE Genetics in Iceland, it is 10 years in Saudi Biobank. However, UK Biobank and the Estonian biobank recruit only adult participants (aged 40-69 years and 18+ years respectively), while in Canada CARTaGENE has a minimum age of 15 years.

The governances of the Icelandic biobank and Saudi Biobank mandate parental consent for participation of children aged $\leq 16$ years and $\leq 18$ years respectively. For Saudi Biobank, either of the parents can give consent; however, the father has superior rights in cases of conflicts of opinion. The child's assent is also sought when possible. None of the biobanks define the age at which children can start giving assent themselves. Furthermore, Saudi Biobank does not ask for re-consent or contact child donors when they reach 18 years, but children can withdraw consent from the biobank. The children will know about their participation either when they give assent personally or when their guardians notify them about participation. The Biobanks Act in Iceland does not refer to re-contacting children when they reach adulthood.

\section{Discussion}

Saudi Biobank aims to conform to international guidelines, as noted in its governance documents; however, differences can be seen with and between other national biobanks, giving each biobank its own unique character.

Before discussing the current situation of the biobank in Saudi Arabia, 2 important factors that might affect the ethics of Saudi Biobank need to be mentioned. First, Islam, which is the religion of the majority of the population of the country, besides being the source of the legal system, colours various aspects of life in Saudi Arabia, including medical issues. Secondly, social characteristics and the tribal structure of the Saudi Arabian community still have deep influences on people's social behaviour. Extended families and consanguineous marriages are common in Saudi Arabia. Although the effects of these 2 factors cannot be separated, they are inter-related and have an influence on certain customs in Saudi society. The precedence of male guardians in taking decisions related to children is an example where we can find both Islamic and social effects. Considering these 2 factors, we will discuss the issues concerning Saudi Biobank in relation to the international guidelines and governances of other national biobanks.

\section{Confidentiality}

We noted that all the governances of the studied biobanks, including Saudi Biobank, mandated respecting the confidentiality of donors, followed certain kinds of practical data protection procedures, such as coding, access policies and security systems, and maintained information confidentiality by making the data inaccessible to biobank staff, insurance companies and other parties. This reflects the importance of this issue; biobank samples and data contain a great deal of potentially sensitive information. Respect for the confidentiality of data is one of the primary concerns of bioethicists (21-23).

Saudi Biobank uses international and national guidelines as references, and grants confidentiality at a level of importance which matches what is stated in the Law of Ethics of Research on
Living Creatures by the Saudi National Committee of Medical and Bioethics (24), and in international guidelines, such as those of HUGO, UNESCO, WHO and OECD, all of which state that maintaining confidentiality of genetic material is mandatory for all biobanks. The governance of Saudi Biobank is fully compatible with these guidelines and also with the respect for confidentiality mentioned in Islamic religious rulings (fatwas) (25).

We observed that Saudi Biobank stresses the issues that result from any potential breaches of confidentiality, such as the risk of discrimination and stigma. The Icelandic and Estonian biobanks also address avoiding discrimination, but Saudi Biobank is the only biobank that specifically addresses this issue in a paragraph in its governance document. Moreover, Saudi Biobank discusses avoidance of stigma. These provisions reflect the sensitivity towards the risk of any type of discrimination or stigmatization in Saudi society. Breaches of confidentially may lead not only to stigma for an individual but also at the familial and tribal level (26). In a society with strong, extended families and a high percentage of consanguineous marriages, any stigma could potentially adversely affect all family members and issues such as marriage. This concern regarding societal/family stigma is supported by other studies about the high rate of consanguinity and genetically inherited diseases in EMR countries such as in Saudi Arabia (27) and among some other Muslim populations (28). There is a growing awareness too in other countries of the need to protect certain groups from disclosure of genetic information, especially after the case of the Havasupai American Indian tribe, in which samples were used without proper consent for research about schizophrenia, inbreeding and human population migration theories $(29,30)$.

Preventing discrimination, as specified in the governance of Saudi Biobank, 
is supported by the Saudi Law of Ethics of Research on Living Creatures (Article 36). There are no specific laws in Iceland and Estonia to prevent genetic discrimination (31); however, both the Icelandic and Estonian biobanks mention preventing discrimination in their governance documents. Even though preventing discrimination has not been stated clearly in the governance of UK Biobank and the Canadian biobank, many legal documents in the UK and Canada offer protection against any kind of discrimination, including genetic discrimination. In the UK, there is no specific law or legislation related to genetic discrimination; rather, the legislators have merged the Disability Discrimination Act 1995 into the Equality Act of 2010, both of which include anti-discrimination measures (32). Likewise, Canada has enacted laws such as Article 15 of the Canadian Charter of Rights and Freedoms, the Canadian Human Rights Act, the TriCouncil Policy Statement and PIPEDA (About Genetic Discrimination). Similarly, in Iceland, the Parliament passed a bill in December of 1998 that permitted the creation of a consolidated record of all the Icelandic peoples concerning genealogy, genetics and personal medical information (33).

\section{Informed consent}

Informed consent is considered to be a cornerstone of ethical practices in conducting medical research, including research biobanks. Informed consent is a reflection of an individual's autonomy, which is a basic principle of bioethics. Obtaining valid consent, free and voluntary participation and clear and adequate disclosure and understanding of information are ethical prerequisites. Saudi Biobank and other biobanks require informed consent to be obtained from all donors. This policy matches the requirements of the Saudi law of research ethics, international guidelines such as the UNESCO Universal Declaration on Bioethics and Human Rights
(2005) and other guidelines about research on stored materials.

One-time consent for all research conducted on donor samples and data has been selected as policy by Saudi Biobank. However, it has received criticism because the donors might not be well-informed about future research using their samples, and therefore the principle of autonomy might be undermined (34). Although these criticisms are recognized elsewhere in the literature, we note that one-time consent matches the requirements specified in international documents and with the findings of other authors of biobank studies (16,25-38). Moreover, onetime consent is the standard selected by many biobanks worldwide (13). Getting informed consent for every instance of research is cumbersome and can therefore be viewed as a hindrance to scientific progress (39). Adequate initial counselling of donors and keeping the door open for further questions and answers is necessary (40). Even if the donor signs consent just once, research ethics committees have to review and approve each research project separately, and the donors should enjoy the right of withdrawal any time. It can be argued that these 2 provisions - ethical approval from an institutional review board and withdrawal rights - offer sufficient protection to the donor $(41,42)$.

The obligation to obtain informed consent before performing research in Saudi Biobank is supported by interpretations of Islamic texts. Although nothing is written in Islamic laws concerning biobanks, the research ethics guidelines issued by the IOMS mandates informed consent before any medical research (36). In addition, Islamic fatwas issued by juristic councils support the obligation of informed consent, such as fatwa no. 161 (17:10) (2006) by the IIFA about Islamic perspectives on medical research (43), the fatwa about stem cells (17:3) (2002) by the Islamic Fiqh Council (IFC) (38) and so on. Moreover, a survey of national research ethics regulations and guidelines in Middle Eastern Arab countries showed that regulations mandate informed consent (8). Although nothing is written about one-time consent in Islamic fatwas, one-time consent does not contradict any Islamic laws.

Most international guidelines consider withdrawal of consent without any adverse consequences to the rights of any participant in a research study. Saudi Biobank offers 3 options for withdrawal, but none of them requires complete destruction of the samples and data. In the 3rd option - complete withdrawal — Saudi Biobank will completely anonymize the samples and data, but it does not require their destruction (6). The Declaration of UNESCO, WHO databases and the HUGO statement provide 2 alternatives for complete withdrawal: to destroy any unused samples and data or to keep them but with full anonymization $(4,16,17)$. The OECD mentions destroying the samples and any data with respect to the cultural heritage and/or religious beliefs of the participant (3). The Singapore Tissue Network and CARTaGENE biobank in Canada will destroy the samples, as will UK Biobank in its 3rd withdrawal option, and prevent information from contributing to further analyses, but not to previous analysis, while Saudi Biobank will keep samples after they are completely anonymized. The Estonian Genome Project will not destroy samples, but destruction may be applied if the identity of a gene donor is unlawfully disclosed. Clearly, sample destruction provides the best guarantee of a participant's protection, but it may result in a loss of research effort and money. Although full anonymization cannot ensure absolute protection, especially in cases of abuse by data key-holders (44), it can offer both protection and respect to a certain degree, in that donors will be informed before participation about the impossibility of complete destruction of their 
samples when withdrawal is requested. Whichever method is chosen, biobanks must make all possible efforts to guarantee sufficient protection to donors. The multiple options for withdrawal of consent at Saudi Biobank are similar but not identical to those at UK Biobank.

\section{Children's participation}

The inclusion of children's samples in research biobanks is widely accepted as being useful, especially to study diseases of childhood (45). This is particularly important at Saudi Biobank due to the high percentage of children in the total population of Saudi Arabia; $77.5 \%$ of the population is under the age of 40 years compared with $49.6 \%$ in the UK. Children are not simply small adults, however, and we cannot just apply the results of research on adults to children. Children's participation in research raises different ethical challenges than for adults' participation. For example, it has been stated that research on children can be performed only if it addresses a medical problem related to a child's health and be beneficial to the participating child or to the community of children. Other conditions for children's participation in research include: minimizing risks to the child; considering the best interest of the child; obtaining the guardian's consent and - when appropriate, based upon the age of the child - the child's assent as well (46-48). Many researchers distinguish between research on children and research on samples taken from children, especially regarding the issue of minimalizing risks $(49,50)$.

Saudi Biobank recruits participants aged from 10 years and over and this differs from many other biobanks, such as UK Biobank and CARTaGENE in Canada. The process is similar to some other biobanks that recruit children among their participants, such as the Icelandic biobank. According to the declaration of UNESCO, WHO databases and the OECD guidelines, research on children is allowed provided the child is offered enough safeguards from more than minimum risks and that the guardian's consent is obtained. Saudi Biobank guidelines also satisfy the OECD guidelines; although the child's opinion is not obligatory, it must be respected, and his or her assent must be collected if possible.

Concerning research on children, the governance of Saudi Biobank is consistent with the opinions stated in several Islamic sources regarding paediatric research, such as the fatwas of IIFA $(67,1992 ; 161,2006)(32), \operatorname{ICF}(3 / 17$, 2002) (51) and the IOMS guidelines (2005) (52). According to Islamic sources, paediatric research has to be in the best interest of the child and must involve no more than minimal risk. According to IOMS the best interest of the child can be a direct individual benefit to the child him/herself or an indirect, general benefit to other children in the population (52).

The same conditions are stated in the Saudi Arabian law of ethics of research on living creations. Using Islam as a reference can explain why Saudi Biobank gives fathers superior rights over mothers in cases of conflict of interest. According to Islamic references fathers are the guardian to their children (53). This is different to the case of Iceland, where due to the different cultural and legal setting the biobank does not specify which parent has superior rights.

However, the question arises, why does Saudi Biobank define 10 years as a minimum age for allowing research on children, when the Saudi Arabian law of ethics of research on living creations does not mention a minimum age? The Icelandic biobank and Marshfield Clinic Personalized Medicine Research Project have no minimum age limit to accept participants. Children younger than 10 years old form a significant proportion of the Saudi population and there is no clear justification provided by Saudi Biobank why the age 10 years was chosen.
Collecting assent from children for their participation in research biobanking is important and consistent with the ethical principle of respecting children's autonomy and including them in decision-making that affects them. The importance of obtaining the child's assent is supported by other studies, and is mentioned in international guidelines about research ethics, such as the Declaration of Helsinki (54), the International Ethical Guidelines for Biomedical Research involving Human Subjects by the Council for International Organizations of Medical Sciences (55), and the Convention on the Rights of the Child by the United Nations (56).

Saudi Biobank encourages (but does not require) children's assent to allow their samples to be used in the biobank and it seems that the minimum age of 10 years was chosen to ensure that participating children are capable of understanding the biobank's principles and procedures and of participating in the decision-making process. The importance of the child's understanding is also mentioned in the guidelines of other biobanks (e.g. in Western Australia). The Council for International Organizations of Medical Sciences state that starting from the ages of 12 to 13 years the child's opinion should be taken into account (55). However, other research sources suggest that $16-18$ years is a more appropriate age for understanding the implications of genetic research and yet others have proposed much lower ages, even as low as 4 years old, when children are capable of understanding their own medical issues (57). None of the Islamic sources define the minimum age at which medical research can be performed on children. In a previous study, we could not find any Islamic fatwa about the age at which children can ethically be considered to be able to give an assent to medical research and suggested collecting assent from children starting at age 7 years (G.H. Alahmad and K. Dierickx, forthcoming, 2014). 


\section{Conclusion}

Saudi Biobank, which is based on international and national ethical guidelines and Islamic religious principles, shares the same fundamental ethical values as other biobanks, although differences could be found on some of the details of the governance. Confidentiality is a sensitive concern, particularly as it relates to discrimination and stigmatization. Informed consent is of course an important issue in all biobanks. However, in contrast to some other biobanks, Saudi Biobank does not have a provision for destruction of samples and data after withdrawal of consent. Participation of children in biobanking is considered important in the context of Saudi Arabia, and they are offered the requisite level of protection by Saudi
Biobank. We propose meeting with other biobanks worldwide for future collaborations and greater discussion and harmonization of guidelines. The governance of Saudi Biobank is one of the newly established health policies in the Middle East that regulate biobanking research and can be adapted partially or completely by other biobanks in the Arab and Islamic world.

Competing interests: None declared.

\section{References}

1. Kaye J, Stranger M. Principles and practice in biobank governance. Farnham, England: Ashgate; 2009.

2. UK Biobank ethics and governance framework. Version 3.0 (October 2007). Stockport, England: UK Biobank; 2004 (http://www.ukbiobank.ac.uk/wp-content/uploads/2011/05/EGF20082.pdf, accessed 4 June 2014).

3. OECD Guidelines on Human Biobanks and Genetic Research Databases. Paris: Organisation for Economic Co-operation and Development OECD; 2009 (http://www.oecd.org/science/biotech/44054609.pdf, accessed 4 June 2014).

4. International Declaration on Human Genetic Data. Paris; United Nations Educational, Scientific and Cultural Organization; 2003. (http://unesdoc.unesco.org/ images/0013/001361/136112e.pdf, accessed 4 June 2014).

5. Qatar Biobank [Internet]. Doha: Qatar Foundation's Biomedical Research Institute (http://www.qatarbiobank.org.qa/ home/, accessed 4 June 2014).

6. The governance of Saudi Biobank. Riyadh: King Abdullah International Medical Research Centre; 2011.

7. International ethical guidelines for biomedical research involving human subjects: an Islamic perspective. In: El-Gendy AR, Al-Awadi ARA, editors. The international Islamic code for medical and health ethics. Volume 2. Kuwait: Islamic Organization for Medical Sciences; 2005:121-276.

8. Alahmad G, Al-Jumah M, Dierickx K. Review of national research ethics regulations and guidelines in Middle Eastern Arab countries. BMC Med Ethics. 2012;13:34. PMID:23234422

9. Saudi Biobank [Internet]. Riyadh: King Abdullah International Medical Research Centre; 2013 (http://www.kaimrc.med.sa/ index.php?option $=$ com_content\&view $=$ article $\&$ id $=31 ; \% 20$ 2013/, accessed 4 June 2014).

10. Grim BJ, Karim MS. The future of the global Muslim population: projections for 2010-2030. Washington (DC): Pew Research Center; 2011.

11. Demographic survey in 1428 AH. Riyadh: Saudi Export Developing Center, Ministry of Economy and Planning Information; 2007.

12. Human Genes Research Act. Passed 13 December 2000 (RT I 2000, 104, 685), entered into force 8 January 2001. Riigikogu: The Estonian Parliament; 2007 (http://biochem118.stanford. edu/Papers/Genome\%20Papers/Estonian\%20Genome\%20 Res\%20Act.pdf, accessed 4 June 2014).

13. Biobanks Act, No. $110 / 2000$ as amended by Act No. $27 / 2008$ and Act No. 48/2009. Reykjavik: Ministry of Welfare; 2009.

14. CARTaGENE governance policies [Internet]. Montreal; SainteJustine University Hospital Center (http://cartagene.qc.ca/ en/governance, accessed 4 June 2014).
15. Vayena E, Ganguli-Mitra A, Biller-Andorno N. Guidelines on biobanks: emerging consensus and unresolved controversies. In: Elger B, Biller-Andorno N, Mauron A, Capron AM, editors. Ethical issues in governing biobanks: global perspectives. Aldershot, England: Ashgate; 2008.

16. Statement on human genomic databases. London: Human Genome Organisation; 2002.

17. Genetic databases: assessing the benefits and the impact on human and patients' rights. Geneva: World Health Organization; 2003.

18. Epps PG. Genetic discrimination. In: Post SG, editor. Encyclopedia of bioethics. New York (NY): Macmillan Reference; 2004.

19. Crocker J, Major B. Social stigma and self-esteem: the selfprotective properties of stigma. Psychol Rev. 1989;96:608-30.

20. Corrigan O, Tutton R, editors. Genetic databases: socio-ethical issues in the collection and use of DNA. London: Routledge; 2013.

21. Giordano J, O'Reilly M, Taylor H, Dogra N. Confidentiality and autonomy: the challenge(s) of offering research participants a choice of disclosing their identity. Qual Health Res. 2007 Feb;17(2):264-75. PMID:17220396

22. Ashcroft R. The ethics of reusing archived tissue for research Neuropathol Appl Neurobiol. 2000 Oct;26(5):408-11. PMID:11054180

23. Deschênes M, Cardinal G, Knoppers BM, Glass KC. Human genetic research, DNA banking and consent: a question of 'form'? Clin Genet. 2001 Apr;59(4):221-39. PMID:11298677

24. National Committee of Medical and Bioethics. [The Law of Ethics of Research on Living Creatures]. Riyadh: King Abdulaziz City of Science and Technology; 2011 [in Arabic].

25. Alahmad G, Dierickx K. What do Islamic institutional fatwas say about medical and research confidentiality and breach of confidentiality? Dev World Bioeth. 2012 Aug;12(2):104-12. PMID:22702346

26. Brohan E, Slade M, Clement S, Thornicroft G. Experiences of mental illness stigma, prejudice and discrimination: a review of measures. BMC Health Serv Res. 2010;10:80. PMID:20338040

27. Al-Gazali L, Hamamy H, Al-Arrayad S. Genetic disorders in the Arab world. BMJ. 2006 Oct 21;333(7573):831-4. PMID:17053236

28. Aziz H, Akhtar SW, Hasan KZ. Epilepsy in Pakistan: stigma and psychosocial problems. A population-based epidemiologic study. Epilepsia. 1997 Oct;38(10):1069-73. PMID:9579952

29. Mello M, Wolf L. The Havasupai Indian tribe case-lessons for research involving stored biologic samples. N Engl J Med. 2010 Jul 15;363(3):204-7. PMID:20538622 
30. Gahlinger PM. Existential pain: impressions from an American Indian reservation. J Pain Palliat Care Pharmacother. 2006;20(2):41-52. PMID:16702137

31. Screening report: Iceland. Chapter 19. Social policy and employment. Brussels: European Commission; 2011 (http:// ec.europa.eu/enlargement/pdf/iceland/key-documents/ screening_report_19_is_internet_en.pdf, accessed 4 June 2014)

32. Statutory Instruments, 2011 No. 2260. Equality. The Equality Act 2010 (Specific Duties) Regulations 2011. London: HMSO; 2010.

33. Personal Information Protection and Electronic Document Act. S.C. 2000, c. 5. Assented to 2000-04-13. Quebec: Privacy Commissioner of Canada (http://laws-lois.justice.gc.ca/eng/ acts/P-8.6/page-1.html, accessed 4 June 2014).

34. Hansson MG, Dillner J, Bartram CR, Carlson JA, Helgesson G. Should donors be allowed to give broad consent to future biobank research? Lancet Oncol. 2006 Mar;7(3):266-9. PMID:16510336

35. Eriksson S, Helgesson G. Potential harms, anonymization, and the right to withdraw consent to biobank research. Eur J Hum Genet. 2005 Sep;13(9):1071-6. PMID:15986039

36. Hens K, Dierickx K. The use of stored tissue samples from minors for genetic research: interviews with professionals. New Genet Soc. 2010;29:329-42.

37. Wendler D. One-time general consent for research on biological samples. BMJ. 2006 Mar 4;332(7540):544-7. PMID:16513715

38. Gibbons SM, Helgason HH, Kaye J, Nõmper A, Wendel L. Lessons from European population genetic databases: comparing the law in Estonia, Iceland, Sweden and the United Kingdom. Eur J Health Law. 2005 Jun;12(2):103-33. PMID:16144230

39. Lipworth W, Ankeny R, Kerridge I. Consent in crisis: the need to reconceptualize consent to tissue banking research. Intern Med J. 2006 Feb;36(2):124-8. PMID:16472266

40. Steinsbekk K, Myskja B, Solberg B. Broad consent versus dynamic consent in biobank research: Is passive participation an ethical problem. Eur J Hum Genet. 2013 Sep;21(9):897-902. PMID: 23299918

41. Knoppers B, Abdul-Rahman M. Biobanks in the literature. In: Elger B et al. editors. In: Elger B, Biller-Andorno N, Mauron A, Capron AM, editors. Ethical issues in governing biobanks: global perspectives. Aldershot, England:Ashgate; 2008.

42. Deschênes M, Sallée C. Accountability in population biobanking: comparative approaches. J Law Med Ethics. 2005 Spring;33(1):40-53. PMID:15934665

43. Decision about juridical regulation of biomedical research on humans. 17/10, Vol. 161. Amman: International Islamic Fiqh Academy; 2006 (http://www.fiqhacademy.org.sa/ qrarat/17-10.htm, accessed 4 June 2014) [in Arabic].
44. Elger B. Anonymization and coding. In: Elger B, Biller-Andorno $\mathrm{N}$, Mauron A, Capron AM, editors. Ethical issues in governing biobanks: global perspectives. Aldershot, England: Ashgate; 2008.

45. Burns JP. Research in children. Crit Care Med. 2003 Mar;31(3) Suppl:S131-6. PMID:12626958

46. Gurwitz D, Fortier I, Lunshof JE, Knoppers BM. Research ethics. Children and population biobanks. Science. 2009 Aug 14;325(5942):818-9. PMID:19679798

47. Hens K, Lévesque E, Dierickx K. Children and biobanks: a review of the ethical and legal discussion. Hum Genet. 2011 Sep;130(3):403-13. PMID:21660506

48. Brothers KB. Biobanking in pediatrics: the human nonsubjects approach. Per Med. 2011 Jan;8(1):79. PMID:21691419

49. Hens K, Van El CE, Borry P, Cambon-Thomsen A, Cornel MC, Forzano F, et al.; PPPC of the European Society of Human Genetics. Developing a policy for paediatric biobanks: principles for good practice. Eur J Hum Genet. 2013 Jan;21(1):2-7. PMID:22713814

50. Hens K, Nys H, Cassiman JJ, Dierickx K. Genetic research on stored tissue samples from minors: a systematic review of the ethical literature. Am J Med Genet A. 2009 Oct;149A(10):2346-58. PMID:19764035

51. Decision about stem cells. 17, Vol. 3. Mecca: Islamic Fiqh Council; 2002 (http://www.themwl.org/Fatwa/default. aspx? $\mathrm{d}=1 \& \mathrm{cidi}=152 \& \mathrm{l}=\mathrm{AR} \& \mathrm{cid}=12$, accessed 4 June 2014) [in Arabic].

52. Hammad N. International ethical guidelines for biomedical research involving human subjects-Islamic view. In: Al-Awadhi AA, editor. Islamic universal charter of medical health ethics. Kuwait: Islamic Organization for Medical Sciences; 2005.

53. Shanweeti M. [The rules of medical surgery]. Jeddah: Maktabet Al-Sahaba; 1994 [in Arabic].

54. World Medical Association. World Medical Association Declaration of Helsinki: ethical principles for medical research involving human subjects. JAMA. 2013;310(20):2191-4.

55. International ethical guidelines for biomedical research involving human subjects. Geneva: Council for International Organizations of Medical Sciences; 2002.

56. Convention on the Rights of the Child. Adopted and opened for signature, ratification and accession by General Assembly resolution 44/25 of 20 November 1989. Entry into force 2 September 1990, in accordance with article 49. New York: United Nations High Commissioner for Human Rights; 1989 (http:// www.ohchr.org/en/professionalinterest/pages/crc.aspx, accessed 4 June 2014).

57. Alderson P, Sutcliffe K, Curtis K. Children as partners with adults in their medical care. Arch Dis Child. 2006 Apr;91(4):300-3. PMID:16399782 